\title{
Youth Vocational Counseling Work: The Redefinition of Duties, the Distribution of Professional Roles, and the Impact of Gender
}

\author{
Sophie Devineau ${ }^{1}$ \\ ${ }^{1}$ Laboratoire des Dynamiques sociales (Dysolab), Normandie Université, Rouen, France \\ Correspondence: Sophie Devineau, UFR Sciences de l'Homme et de la Société, Rouen Normandie Université, \\ Rue Lavoisier, 76821 Mont Saint Aignan, Rouen, France. E-mail: sophie.Devineau@univ-rouen.fr
}

Received: January 18, 2017

Accepted: January 30, 2017

Online Published: August 16, 2017

doi:10.5539/res.v9n3p140

URL: http://doi.org/10.5539/res.v9n3p140

\begin{abstract}
The 1960s myth that good vocational counseling means successful youth entry into employment is back in favor and imposing itself on educational policy as an absolute priority during this period of high unemployment. But implementation of these youth career planning and employment policies has largely been delegated to local-level authorities, where interventions now take the form of reticular projects.

This is the context in which we test the hypothesis of a crisis in the work of actors providing youth vocational counseling, program coordinators of various ranks, psychological counselors, and referent teachers working with students.

The methodology for the main study is based on interviews with a range of professionals. A supplementary study analyzed the content of articles in "L'echo des régions", the magazine of the Association of the Regions of France, from 2010 to 2015.

One finding to emerge from these observations is that the educational system internalizes concerns connected with job openings in occupations, while actors focused on post-scholastic job placement request more general education. This role inversion highlights the main contradictions running through youth vocational guidance. All actors attest to the limitations thwarting their voluntarism as well as to the dilemmas they face. Among the identified obstacles are the individualization of vocational paths and the emergence of case-by-case counseling, the application of the principle of equality to competing strategies, the disorganization of institutions allocated declining financial resources, conflicts of interest in partnerships, devalued courses of study, and insecure jobs. We also observed that the proffered arguments propose handling youth career counseling and entry into employment according to an "emergency response" model. In such a landscape devoid of egalitarian prospects, it nonetheless emerges that the path toward the equality of girls with boys is more open. At the same time, an opposing gender logic appears in the distribution of professional tasks, with particular consequences for women and especially female teachers.
\end{abstract}

Keywords: local politics, career planning, entry into employment, deinstitutionalization, gender

\section{Introduction}

The work of providing youth vocational counseling has been changing in recent years, as a result of an overhaul in the allocation of duties among a range of professionals and the rising sway of entrepreneurship as a model for public policy intervention as it has penetrated every sector of contemporary social work (Boltanski \& Chiapello, 2005).

The logic of the 1960s that education and training should respond to workforce needs and that good guidance leads to successful integration of youth into the workplace is in favor once again and is being imposed in educational policy as the absolute priority in this period of high unemployment (Agulhon, 2003). But instead of a centralized national conception, the implementation of public policies for the career counseling and placement of young people is largely delegated to local levels, where intervention has subsequently taken the form of individualized youth counseling conceived under the auspices of projects launched by the relevant authorities at various lower administrative levels (Lafore, 1999; Greffe, 2005). This movement flourishes thanks to the voluntarist and entrepreneurial ideology supported by the last thirty-some years of the decentralization of State missions (Berthet, 1999), and in this spirit, there have been proposals to free the way for innovative local 
initiatives, set new directions for responsibilities to be assumed, and bolster the enthusiasm of actors in positions of responsibility. Actions promoting the local image have also emerged, aiming for "visibility" on the competitive national, European and international scenes.

This is the context in which we will test the hypothesis that there is a crisis developing in the work of actors charged with counseling young people, program coordinators of different scales, elected officials, psychological counselors, and teachers whom students ask for advice. Among the manifestations of this crisis we will pay particular attention to the obstacles such professionals encounter as they go about their work. By examining their working conditions and how their work is organized, we will explore how these people in positions of responsibility evaluate the effectiveness of what they put in place and the status they attribute to the objective of egalitarianism for their clientele, which is the guiding principle of public intervention and the individual province of their engagement in such counseling work (Bidet, 2011).

Curriculum counseling in France relies on statistical data on student flows in various fields of study and students' careers in the educational system until their arrival on the job market. Status reports are thus made regularly, mainly resulting from studies by the DEPP (Note 1), the CEREQ (Note 2), student life observatories, the CARIF-OREF-RCO network (Note 3) and the CREFOR network (Note 4) in Normandy. Taken together they describe the events that have objectively punctuated this period of training, guidance, and job placement in young peoples' lives. The wealth of data concerning young people contrasts with how little is known of the actors governing counseling at various institutional or political levels of a given region. Gathering their accounts is thus primarily intended to fill a gap, one that is all the more harmful because the current French vocational counseling system relies on a strategic approach and all steering of anticipated interventions has been decentralized to regional and more local authorities (Dubar, 2001; Dubet, 2002; Tharin, 2005). The notion of a "training area", which feeds into the idea of adapting the local job training supply to the demand of the available jobs, underlies the explicit finality assigned to public intervention since the law on curriculum counseling was enacted more than five years ago (Note 5).

Questions from the sociology of work that explore the professional dimension of intervention will be central to this analysis in the field of education, as it strongly structures the motivation of the interviewed people in positions of responsibility as they transition from hierarchical professional bureaucracies to networks of diverse organizations (Bertaux \& Hirlet, 2012). This particularly relates to counseling professions caught up in a de-professionalization process modeled on temporary program coordinators working on limited projects (Champy, 2014), but also to the re-regulation of the parameters and content of the work that redefines the space of public intervention in youth counseling (Demailly, 2012). Of prime importance here is the description of the working conditions for counseling as experienced by the people responsible for it locally, and their analysis of how youth vocational counseling operates today.

\section{Method}

The chosen methodology for the main study primarily consists of interviews with the range of relevant professionals in Normandy. A supplementary study concerns content analysis of articles in "L'écho des régions", the magazine of the Association des Régions de France (Association of the Regions of France) from 2010 to 2015 (Note 6). A preliminary study was conducted with the educational authorities and prefecture of the region of Haute-Normandie, in their services for youth education, training, and employment. The sample size is modest by definition ( 21 interviews) because it only concerned the few people in positions of responsibility charged with regional, municipal, departmental, school district, or academic responsibilities in the field of youth vocational counseling.

\section{Results}

\subsection{The Injunction to Entrepreneurial Initiative}

The national injunction for local-level counseling emerges in the absence of a unified general policy and in a context of declining financial resources. Especially deplored are quantitative objectives that take no account of the content of the occupations providing such advice. Under such conditions, decentralization turns out to have little benefit for inter-regional social justice missions. Citizen equality within a given part of France does not seem to be assured, while the scale for geographical mobility is established at the European level.

It falls between two stools, with one in freedom and one in great limitation, ministerial limitations. Every day we get circulars and we can't do what we want and at the same time there's no money... so anyway, I mean, it's kind of a mess (Education program coordinator, SUIO - a university career center). 
Decentralization... Well, we are still really afraid, it's more about the equality of citizens in the region, it's the fundamental question of a region's social justice (Mission Locale-a publicly funded network of youth employment centers).

Putting equality into practice at the local level runs quickly into obstacles, not all of which relate to information on young peoples' futures. Some glitches in the political organization itself are thus highlighted, indicating a rather serious situation. The lack of an educational strategy clearly structured around the objectives laid out in the Ministry of Education's directives leads to a feeling of confusion and isolation.

Yeah, I have a duty, and well, it's a duty, um, because there are political engagements, um, well, that today seem kind of strained to me but that were... Strained in national terms, in counseling terms, um, of the uh Ministers of Education. I, like, set the bar high, I mean, there's no... well there's less of an impetus today (Education program coordinator, local educational authority).

Program coordinators have to develop strategies, which they work out according to their networks and goodwill. Backers of potential programs are entrepreneurs wasting away in a multi-form decision-making universe that they muddle through with no guarantee that their actions will have a lasting effect. As Marc-Henry Soulet has stressed, the logic of the project (in the sense of potential plans to be borne to fruition) indeed produces heteronomy rather than autonomy (2012). A collection of the acronyms for such regimes illustrates how dispersed counseling is. A whole string of labels individualize projects, whether they are in competition or networked in partnerships: DALEC, PRE, CUCS, CRED, ARCOL, EDRESUP, ZEP, REP, ZUS, CASNAV (Note 7). The centralism of the injunction to counsel relies on a great freedom of means for doing so:

From the moment that people are convinced of their project, they can fund it. (...) Yes, the department established its own CUCS, as it were. It's the CRED (Note 8). There's still a left-right conflict, the department doesn't want to split funding with the State, it wants to do its own things. We are in a democracy and you can't deny there's a degree of competition (Education program coordinator, Prefecture).

As far as easier or even harmonious functioning is concerned, partnership biases and networking appear to be misleading, because interests certainly diverge on the subject of education. The principal of justice varies according to the cause and its defender, be it the school, parents, or even local governmental administrations. For teachers the principle of equity is applied in the classroom or the school-level at most, while for parents the scale shrinks to their child's interests; these perspectives remain unfamiliar to program coordinators, who think at the scale of an administrative area, a perimeter of intervention in competition with others at the national level.

It's even harder to spread the logic of equality. The logic of a region, now that's even more difficult. I tend to call the parents anyway... I think of them more as a lobby group than a partner, to be perfectly blunt (Education program coordinator, city-level).

Using vocational counseling as a solution to haphazard educational paths stems from two conceptions of the problem of youth unemployment. The split in perspectives does not fall along lines of status between elected officials and civil servants, but instead arises from the variations in their experiences of their differing duties. When those in positions of responsibility agree to intervene in the educational and training system, their analysis stresses job opportunities and occupations. Thinking is thus focused on the internal functioning of courses of study and comes with a desire to regulate flows, controlling them by more directive counseling measures aimed at students, parents, and teaching teams. In sum, the educational system should internalize the demand for particular occupations and professionalize the training program accordingly, starting with lower educational levels.

There the PRDFP (Note 9) is evoked and the... a whole change in intellectual workings that dates back to 2001, the extent of which we have yet to fully comprehend. I'll explain. Before 2001 everyone started with the clients' needs, at the level of the client, by saying, "This is where people are, what can be done so they move forward?" Starting in 2001 when training became part of the equation in the ASSEDIC (Note 10) training market, thinking entirely reversed and as natural as can be worked its way into peoples' minds, and it's "What does business need and how to get people to respond to these business needs?" It's completely backward, so one thing's certain, it can only distort... Except that one thing's certain, no-one looks at the clients anymore and no-one's interested in them any more... and it's going to get more and more distorted (Mission Locale).

Conversely, people in positions of responsibility in direct contact with the job market look to economic analysis of the conditions for youth employment, which supports raising young peoples' qualification levels in order to 
increase their likelihood of being hired in competitive conditions with high unemployment and given the dramatic changes occupations are experiencing.

In terms of joining the ranks of the employed, we are especially confident in collective guidance. We have a European program that has been working for several years that is a multi-lateral exchange with five countries, where the young people are completely invested. It's true that all the young people that have gone through this program leave it transformed, and so they acquire an independence that is useful for the rest of their lives (Education program coordinator, city-level).

Since a roofer has to be able to do electricity to be able to install solar [panels], so, that indeed requires abilities. I mean, a roofer today needs a certain number of skills. And the level will really increase a lot. Because if you only have Bac +2 [the baccalaureate exam capping the end of secondary school plus two years of further study]... You can't become a roofer in two years (Mission Locale).

According to professionals spending time with young people in difficulty at Local Mission offices, counseling is at best presented as a stopgap measure once all other possibilities have failed. To the contrary of the preceding approach, this reasoning suggests externalizing the employment market's direct demands to outside the domain of education and training.

The main concern related to job placement is not so much job placement-I almost want to say that I feel that there are more young people who are working in their career, even at the beginning of their career, than in '86. When I joined the network, basically young people were not qualified, it was enough to get them qualified so they could get a job. But that's not where we are anymore in relation to the job market, in this configuration... I want to say that whatever the occupation, over 20 years we are still sure of the occupations that have gotten much more insecure for young people-we're talking $80 \%$ of jobs that [only] last for three months or are temping. Our biggest challenge is getting those jobs to become steady. That is, we're talking about paths to a career that are getting longer and longer (Mission Locale).

The issue of equal opportunities at school is the key motivation for their actions, since they know that their region is statistically below average in general and long courses of study. They evaluate working-class youth's needs using statistics on schooling. They are additionally faced with relocations that make established training programs a waste, despite the National Education system having fulfilled its end of the bargain by raising young peoples' qualification levels.

Best placed to assess the limits of local action, those in positions of responsibility are sometimes brutally confronted with failures in youth employment. Several examples come from civil servants who were very disappointed following the abandonment of re-training plans whose creation had made great demands of their wills and energies. Elected officials embittered by their failed experiments in increasing the job supply provide other examples. In every cited case, local government policy was to be very inviting to large companies so that youth in the region would benefit directly from the godsend of new jobs. The hope was to get young people having left school without qualifications and struggling with unemployment into the ranks of the employed using the regional training system, but these young people were ultimately not included among the hires. The indicated obstacles in this case come under the right to employment: depreciating courses of study leading to insecure jobs, no obligation for newly arrived companies to hire re-trained young people for these jobs, the longevity of these jobs.

I mean, it's, it's... in a market logic, it's the employer who hires. It hires whomever it wants. The people who went through the programs, the people matching public authorities' plans or not... the employers are under no obligation. We will establish... we used the ASSEDIC, we used the General Council [of the administrative department], we anticipated establishing a certain number of training programs to prepare people of all ages to be able to hold jobs in this much-talked-about company... After, the employer will hire the people that are presented to it, will hire others, will move people working on the other side of France to bring them here... well, anyway (Mission Locale).

Contrary to commonly held conceptions denigrating the supposed inertia and archaism of the educational system, a number of innovations have been tested in this domain, with much creativity and professionalism. The goal of these various projects was inspired by the most elementary logic of the balance between supply and demand, the same one that serves as reference to current entrepreneurial voluntarism. One example we were given deserves being appreciated in the full context of the SUOI-led program, so conscientious was the endeavor's conception and implementation. We must restrain ourselves to present only its result: 
Teachers were fully involved, the whole team worked $100 \%$ on this project, so every link counted... and well, I don't dare give you the result. It took up seriously nearly three months of energy, and so a whole counseling team that, I dunno, there's maybe 20-30 people in this program. We succeeded in making ZERO — not ONE applicant showed up at the school, not one. [...] So the reorientation mechanism, I wanna say, I don't know what it is any more, it's individuality (Education program coordinator, SUIO).

It is also quite tempting to turn to teachers and ask them to do something other than their job, to leave their specializations (that are moreover the object of their professional careers) to take care of guiding young people. It is additionally worth noting the extent to which the entrepreneurial model has penetrated that educational world, including its vocabulary, clashing head-on with a whole culture of long-term collective good. An education program coordinator for the Prefecture expressed it thusly: 'It was all new since we haven't even had this program for a year yet. The problem is that we had trouble selling it and we could see the students had reservations". However, throughout the research, a variety of people responsible for such programs continually cited teachers as partners of preference for their initiatives.

I feel like I am rather supported there, when you want... when we say we can't actually leave young people by the wayside without any training, with no opportunity to move toward employment, there, yes, there is really a response from teachers (Elected education program coordinator).

Every time I tried to do something at a school, with teachers, on the issue of equal opportunities, I had a pretty good response, with some people who went the extra mile, so people I could really work with, so, cooperation (Education program coordinator, local school authority).

In the end, the mandate that youth vocational counseling coordinators orchestrate business initiatives to create local solutions to youth employment problems does not appear to deliver the tools necessary to performing their duties successfully. And although they say they are backed by teachers' goodwill, teachers themselves describe their contributions as muddling through (Note 11).

\subsection{The Urgency of Action}

Voluntarism at the local scale is signaled through the treatment of counseling as an emergency response. People in positions of responsibility affirm that if the success of all children is of utmost importance, it follows that it is imperative to offer training in fields corresponding to available jobs. The very notion of education evaporates before the imperative to prepare for an occupation, without this reduction of education ever being discussed directly by the people in charge; this partly relates to the fact that it is a domain reserved for the school, and partly attests to its renunciation given the limited time available for policy to act. In addition, focusing on young people's personal plans obliges case-by-case "management", individualized guidance removing gender or class background questions from consideration, along with any real inequality issues. This new counseling rationale consequently clouds the explanatory points of reference structuring students' social situations. Case-by-case handling replaces overarching policies for equal opportunity, putting individual and family strategies in the foreground (Soulet, 2008). But how to equitably manage a multitude of individual strategies? Much more than limiting the reach of vocational counseling policy, individualized guidance is a genuine obstacle of an ethical order, another impediment to the search for satisfactory interventions.

We can also measure the feeling of urgency in vocational counseling through behavioral changes in young people and their families. Everyone bands together to better respond to what seems to be an essential decision.

The clientele we absolutely never saw 20 years ago was the clientele of parents. Now we see parents (...) and then we have grandparents (...) We also see them in the registration lines, it's not rare, whole families come to sign up the kid (Education program coordinator, SUOI).

If in the past individual futures were a matter of personal choice and a right of passage into adulthood, today those futures are counseled, as the prospect of independence grows distant and the challenges of getting a job become sharper. In twenty years, individual paths to employment have lengthened and policy has gone from a logic of qualification to one of public intervention through counseling (Circulaire du Ministère de l'Éducation nationale, 2008).

Despite past, perhaps unsatisfying counseling or career re-orientation experiences, the voluntarist discourse nonetheless shows its full persuasive strength by developing even further, despite its observed previous failures. Career planning is treated in urgent terms as early as middle school, and education is approached as a risky situation for young people. Students seem to be in danger of dropping out of the school system, leaving without qualifications, and suffering unemployment, while people responsible for education are tormented by the 
imminence of the danger. The discourse about youth counseling is anxious, to say the least: it exhibits the vulnerability of young people, the risks of dropping out, and the lack of vocational training meeting employers' needs. Local-level policy intervention consequently proves to be limited to philosophical solidarity (Ballain, Glasman, \& Raymond, 2006; Blais, 2009). Every year students leave school that then "have to be counseled", an observation that calls for compensatory actions. The extent of voluntarist discourse coming from people in positions of responsibility is striking, while at the same time they have to resign themselves to plans with very modest ambitions that contrast with their mission for change. In government-commissioned reports, the power of social observations is rather well encapsulated in their titles such as "A generally worrying observation" and "Curriculum counseling: Mechanism for exclusion?" The social determinants of scholastic success that ensure social reproduction through schooling thus occupy a significant place in these reports. For instance, they emphasize that, "student guidance and final qualification levels are conditioned by the structure of the educational supply". They detail a program of objectives to be met to reduce the "successive exclusions" and "the problem of scientific courses of studies", and to ensure success in "treating difficulties in school", "achieving equality for girls", and "responding to the particular needs of the employment market". Such social knowledge, which is moreover shared by local authorities, only holds a minor place in the conception of their interventions, however. Once the relevant social observations are established and economic norms correctly estimated, public intervention for vocational counseling focuses on rapid and individualized intervention at the end or fringes of educational careers that have already been decided, rather than at the source of the social structures to be softened.

The timing of such public interventions, made rapidly and after the fact, has the major consequence of addressing individual problems that have likely become more complex with time, by having avoided the worst instead of seeking the better. In this spirit, a distinct fatalistic tropism marks the body of discourse of actors in counseling. It also contains compassionate notes insofar as it is sometimes necessary to look for immediate solidarity and admit that equality is not the priority in such times of high unemployment. The threat of job insecurity or even full exclusion hangs over every consideration, and to a certain extent it is impossible to think in terms of young people to be educated or citizens to be trained. The very short term replaces the long term, thus imposing shifts in reasoning, from the right to an education to the right to a job, from equal opportunities to the simple possibility of joining the working world. The obstacle is thus of a philosophical order as well, since by curbing substantial educational ambitions, the urgency of the action limits the ability to project into a wide-open future.

We can develop in favor of employment... we implement policies allowing everyone, or at least as many as possible, to get a job and so that's also a form of equality, or at any rate, developing equality to be able to get this job (Education program coordinator).

This rationale approaching jobs through training is supposed to appeal to common sense: "Hardly a day goes by without me meeting a company that expresses its difficulty finding the right profile, hardly a day when I don't meet a young unemployed person that tells me 'I can't find a job" (Note 12). But the real nature of occupations produces another narrative:

The realities of occupations are not always easy. For example, we talk about hospitality and culinary occupations, where a lot of youth are trained, guided toward those occupations, but where the fact nevertheless remains that it's still a lot of insecure jobs. So after a while young people, well they get discouraged, stop, and plus, with the hours, mobility problems since there are practically no employers anymore, including those for contracts for school-mediated internships for that matter, that house their employees or apprentices. So it's true that it's mobility problems, it's also mobility-related costs, it's also working hours that are thankless and that further accentuate mobility problems, and that's it (Mission Locale).

Generally employers either turn to young people that have acquired a high level of general education or they do not pay commensurately for the degree, which leaves the training/job relationship just as elusive (Tanguy, 1986) and the qualification undecidable (Tripier, 1991). This is because there are some serious contradictions between professional training and polyvalence scattered through employers' federations' conceptions of employability. All of this leads counseling and employment actors to look for simple, immediate answers, as poorly qualifying as they may be for young people.

So for three years now, really intensely, with the support of the nonprofit sector, we are looking for a way to match training to the available jobs for a young clientele from the neighborhoods. And we do it in a system of very reactive interventions, short training programs that allow these young people to get 
a job, so that's an initiative of the city's social cohesion service, we are charged with implementation (Education program coordinator, city-level).

\subsection{Powerlessness, Retreat, and the Paradoxical Effects of Gender}

The narrative of vocational counseling coordinators is ever marked by a double register, one deploring the unstable, complex, and quite vague environment for carrying out their actions and another explaining the content of their work in detail. The exactitude applied to examples drawn from their personal experiences signals the depth of the concern they have for their work. Their professional investment is manifest and explains the disappointment they feel in face of the outcomes of their projects, not to mention a certain suppressed anger. Their discourse fluctuates between irony to distance themselves from the bitterness of seeing the situation get worse despite their efforts, and invective addressed to public authorities. None of our interviewees spoke of their activity with enthusiasm, or even with simple satisfaction or happiness at work (Baudelot \& Gollac, 2003); to the contrary they seemed to be overwhelmed by the weight of their duties, which they experience as unattainable.

Among those in coordinator positions, there is an unexpected degree of distress in face of the amplitude of the task they are to accomplish with neither guidance nor help, and perplexity in face of the absolute disorganization of this decision-making world without decision-makers. This results in a feeling of confusion, isolation, and having to muddle through alone at the local level without any ministerial contacts, framework, or action plan. The centralism of the mandate to counsel is in fact paired with a great neoliberalism of the means to do so, and some wonder if a national policy for youth career orientation actually even exists.

So the State completely disengaged... since the State, uh, is exclusively, it's clear with program $6 \mathrm{~b}$, it's clear with a certain number of things that are flagged like that, it's the fastest possible access to employment, whatever the length and conditions of the job, no-one is interested in that, but the fastest possible access to a job (Mission Locale).

These schemes came with the gradual disengagement of those who had put them in place, bit by bit the funding schemes decreased. The schemes used to be backed by the Ministries of sport and youth, and, uh, gradually, with every new scheme, y' know, every three years we changed... so anyway, the funding decreased (Elected official, representative at the Region).

A vague sentiment of powerlessness threatens, between the surplus of responsibilities at the local level and the lack of interlocutors:

Well, uh, for example, apparently there isn't a delegate any more. All the program coordinators on this question were brought together at least once, maybe twice, every two years, there was really an inter-ministerial delegate, uh, in education, et cetera. I can't find a name anymore, or I find really, really old things, I'm not sure that it's been updated, I can't find anyone who'd be... who I could call, who'd be in a Ministry for example, even just that. Well after, um, in the school districts I obviously don't find, uh, great means disbursed to these program coordinators, while me here, it's a small district but, um, in other big districts I don't have the impression that there's really, um, considerable means given, as a general rule (Program coordinator, local educational authority).

This difficulty is compounded by those added by a State that is good at "communication", or public relations. When priorities have to be ranked, it is not rare for the top spots to go to interventions propitious to creating an "event" and assuring a degree of publicity.

Uh, I wonder if, to be honest, if that's not where I'm going to have the most significant stumbling block. He thinks that his duties and role are mainly to do communication, and I'm not at all in that niche, so already we're divided on our way of, of... (Education program coordinator, local educational authority).

Lacking most of all is the very import of the an overarching policy structured around the priority of educational equality for all:

So there's kind of a way of talking like that, of impotence. And, um, I think that we're trying to move to another phase, to something else, and that there's some kind of wavering, uh, that, that's looking for its way, too, and that I'm looking for too, in a certain way, anyway. Well, but then it might also be that I'm not sure that there is one even if we see it, I'm not sure that it's a political priority either, y' know, um, the issue of diversity or equal opportunities aren't necessarily priorities in terms of the crisis throughout the school system, a crisis in teaching, all these questions that are still, at the same time, part of the rest of it, y' know... (Education program coordinator, local educational authority). 
Most of the career-counseling actors that we met have the typical sociological profile of State or local civil servants, and consequently observe the usual reserve while expressing their professional or general ethos in support of public services and equal opportunity (Quintane, 2008). The situation is thus far from an un-nuanced desire to import these managerial methods into State institutions. Attachment to egalitarian values and an ethic of general interest run up against these new modes of management that prevent these professionals from reaching their objective of work well done. Their proximity to young people most likely explains their propensity for working for others (Laforgue, 2009), which makes their dissatisfaction more acute. The consequence we observed among a majority of interviewees is considerable destabilization, due to uncertainty over the duties themselves and the crumbling of the symbolic arrangements of professional mobilizations (Demailly, 2012): "Outside funding has to be found for these projects, and the question of legitimacy is raised. But in one sense I can also understand it; they start from the principle that they are the ones who are teaching students, and they don't like it when they're worked around", according to an education program coordinator working for the Prefecture.

Some paradoxical consequences result from actors' renunciation of ideals when overwhelmed by the scale of economic difficulties they think will never improve. Although the question of equality between the sexes was not a primary concern, developing projects to that end seemed to be in the order of the possible in comparison to actions for other ends. In line with observations made of the human resources directors in large companies and their use of diversity as a new managerial category (Bereni, 2009), "gender"-labeled projects prompt a certain reaction in regional administrations, especially because of the financial support available for European Union policies. People responsible for the project agree in saying that it is relatively easier to pursue this form of equality with the cooperation of all partners. Furthermore, the teaching milieu is more open than others to gender equality, another non-negligible factor facilitating the success of diversity projects.

I think that there's maybe more... well, I don't know, maybe more consensus on working on equal opportunities for girls and boys than on privileged/underprivileged aspects and all those questions that could be... I'm not sure that it has as much consensus as girls/boys. Maybe it's even more difficult to work on equal opportunity in general in relation to populations. It's almost easier to raise the subject with them [teachers] than to go into a company and work on it with people that work in a company-I think that it's easier in the teaching milieu than it is outside (Education program coordinator, local educational authority).

Even if the concern today is especially for the 13 to 16 year olds, we have trouble... There are very few 13 to 16 year olds in vocational re-orientation programs, which leads one to think that they are staying home. And that you find with girls and boys. But more among girls, and over age 16, too. Young girls seem to stop much more without looking any further (Education program coordinator, local educational authority).

Diversity efforts thus open up potential actions to girls, who turn out to be less equipped and less helped for a fresh start than boys. Their obstacles are clearly identifiable and, more importantly, can be addressed in projects involving changes in specific courses of study and developing those that remain gendered. There are also some seemingly attainable actions to inform youth on occupations that are too often depicted in a gendered way. This could even work toward a favorable situation in companies that can no longer cover their workforce needs by simple reliance on the family-based father-to-son system.

I think that we've also got to fight for child-care providers, because there's also sectors that are entirely female, I think that it's... this particular equality should be in all occupations, and that regardless... well anyway. And it's also a mess for some boys to go into some sectors... (Education program coordinator, city-level).

On the boys' side, in male, rather male programs, there was probably a work of... I'm thinking of metallurgical programs, for example, which used to be a program with a lot of dropouts - there's a lot fewer now. The frames of reference have changed, but concerned institutions made an even greater effort in terms of external communication on female programs (Education program coordinators, city-level).

However, the arrival of this new vocational counseling management has other effects that crystalize or even re-enforce gender relations. In schools, and contributing to the dismantling of the profession of guidance counselor-psychologist, the duty of informing and counseling young peoples' career planning falls on the teachers that are willing to be students' primary teachers, especially in years that are essential to career planning like the final year of middle school. School principals thus more willingly and insistently solicit male teachers to 
do this work in the final year of middle school, thinking that women seem to be "naturally" more likely to fulfill the maternal role of counseling younger students just starting middle school (Note 13). Gendered stereotypes figure fully in the choices of principals stating they look for men for final-year advising, which comes with a much higher annual bonus than first-year responsibilities. The gendered hierarchy of school work is thus supported by an internal organization of the distribution of tasks and responsibilities discriminating against female teachers for their supposed feminine qualities while affirming the privileged status of male teachers, who are supposedly graced with the just as stereotypically masculine quality of authority. The paradox is that male teachers accepting this responsibility cite the very work of guiding and helping students and working with the family as the main motivation for assuming the additional work.

\section{Discussion}

Youth vocational counseling includes a wide range of statuses, occupations, and duties; strongly present in secondary schooling, it also concerns young people who dropped out of the educational system. The redefinition of how tasks are organized and professional roles are distributed among program coordinators in projects involving multiple networked actors leads to a widespread destabilization of what is specifically allotted to each of them. The nature of this work, intricately conceived in networks applying their skills to variable scales guided by the principle of entrepreneurial initiative, makes the intervention of each of these professionals even more complex. This weakening occurs through what seems to be a great freedom of action, but with no guarantee of the means for taking action and lacking any frame of reference specifically supported by knowledge constituted within a specialized profession. This muted de-professionalization makes it difficult to mobilize actors' skills and leads to a form of powerlessness:

In any case it includes forms of "responsibilization", meaning transitions to new forms of independence, the individual having to invent the means for producing the expected outcomes. This new form of independence-prescribed, guided, controlled - is in line with a normative frame reducing the obligation of means in relation to the obligation of results (Demailly \& de la Broise, 2009).

We are thus witnessing a crisis situation in youth counseling work, one symptom of which being the dramatization of what could be a simple step in the lives of young people passing into adulthood and independence through access to employment after a period of training. Management of the flow of young people and short-term actions thus frustrate the broader objectives of a society that values knowledge.

Among other observed effects, we can see an inversion of expectations and roles: teachers and principals request more working relationships with companies and imagine their duties in terms of access to jobs in particular occupations, while local program coordinators are expecting a more general education from the school system and think more in terms of qualifications and the European and international employment markets. The entrepreneurial organization is coupled with a renunciation of the egalitarian principle for youth from working class backgrounds, who are already considered lucky if they get a job.

As a whole, those responsible for youth vocational guidance express a feeling of powerlessness and retreat in projects that find greater resonance in European policies and sometimes in companies. This is how an assortment of projects intended to improve equality support specific actions for the career orientation of girls and boys.

At the same time, since vocational counseling is considered to be a matter of authority, the effects of gender are also manifest in the fossilization of stereotypical task distribution between men and women counseling young people in the school system. This observation also holds true for the program coordinators in our study, less than a quarter of whom were women.

\section{References}

Agulhon, C. (2003). Construction des relations formation-emploi. Une tentation adéquationniste renouvelée. In P. Doray, \& C. Maroy (Eds.), Les relations entre économie et éducation. Vers de nouvelles régulations? (pp. 51-67). Bruxelles: De Boeck Université.

Ballain, R., Glasman, D., \& Raymond, R. (Eds.). (2006). Entre protection et compassion. Des politiques publiques travaillées par la question sociale. Grenoble: PUG.

Baudelot, C., \& Gollac, M. (2003). Travailler pour être heureux. Le bonheur et le travail en France. Paris: Fayard.

Bereni, L. (2009). Faire de la diversité une richesse pour l'entreprise. La transformation d'une contrainte juridique en catégorie managériale. Raisons politiques, 35, 87-105. https://doi.org/10.3917/rai.035.0087 
Bertaux, R., \& Hirlet, P. (2012). Emprise des institutions et autonomie professionnelle: Des effets de place et de génération. In F. Aballéa (Ed.), Institutionnalisation/désinstitutionalisation de l'intervention sociale (pp. 107-115). Paris: Octarès.

Berthet, T. (Ed.). (1999). Les régions et la formation professionnelle. Paris: LGDJ.

Berthet, T., \& Cuntigh, P. (2002). Politiques d'emploi et territoires. Bref-CEREQ, 182, 1-4.

Bidet, A. (2011). L'engagement dans le travail. Qu'est-ce que le vrai boulot? Paris: PUF. https://doi.org/10.3917/puf.bidet.2011.01

Blais, M. C. (2009). Qu'est-ce que la solidarité? In S. Devineau (Ed.), Justice Sociale, Innovations et Sociétés (pp. 81-93). Paris: L'harmattan.

Boltanski, L., \& Chiapello, E. (2005). The New Spirit of Capitalism (E. Gregory, Trans.). New York: Verso.

Champy, F. (2014). Faut-il parler de déprofessionnalisations au pluriel? Tentative de thématisation de deux processus de remise en cause de pratiques professionnelles. Recherche \& Formation, 75, 133-146. https://doi.org/10.4000/rechercheformation.2191

Chirache, S., \& Sauvageot, C. (2003). Prospective emploi-formation à l'horizon 2015. Note d'information-DEP: 06.03 .

Demailly, L. (2012). Désinstitutionnalisation ou changement institutionnel? In F. Aballéa (Ed.), Institutionnalisation-désinstitutionalisation de l'intervention sociale (pp. 17-31). Paris: Octarès.

Demailly, L., \& de la Broise, P. (2009). Les enjeux de la déprofessionnalisation. Socio-Logos, 4. Retrieved from http://socio-logos.revues.org/2305

Dubar, C. (2001). La construction sociale de l'insertion professionnelle. Education et sociétés, 1(7), 23-36. https://doi.org/10.3917/es.007.0023

Dubet, F. (2002). Le déclin de l'institution. Paris: Editions du Seuil.

Greffe, X. (2005). La décentralisation. Paris: La Découverte.

Haut Conseil de l'Éducation. (2008). L'orientation scolaire. Bilan des résultats de l'école: 08-04-2010. Retrieved from https://www.hce.education.fr

Jaggers, C. (2003). Forte baisse de l'emploi des sortants de lycée et d'apprentissage. Note d'information—DEP: 04-21.

Lafore, R. (1999). Services publics locaux et cohésion sociale. In S. Decreton (Ed.), Service public et lien social (pp. 369-398). Paris: L'Harmattan.

Laforgue, D. (2009). Pour une sociologie des institutions publiques contemporaines. Pluralité, hybridation et fragmentation du travail institutionnel. Socio-Logos, 4. Retrieved from http://socio-logos-revues.org/2317

Quintane, G. (2008). La désinstitutionnalisation de l'administration. In J. P. Bras (Ed.), L'institution. Passé et devenir d'une catégorie juridique (pp. 175-204). Paris: l'Harmattan.

Soulet, M. H. (2008). Vers une nécessaire individualisation des politiques sociales? In D. Vrancken, \& E. Thomsin (Eds.), Le social à l'épreuve des parcours de vie (pp. 59-76). Louvain la Neuve: Academia-Buylant.

Soulet, M. H. (2012). L'individualisation de l'institution? Constats et hypothèses. In F. Aballéa (Ed.), Institutionnalisation-désinstitutionalisation de l'intervention sociale (pp. 55-64). Paris: Octarès.

Tanguy, L. (1986). L'introuvable relation Formation-Emploi. Paris: La Documentation Française.

Tharin, I. (2005). Orientation, réussite scolaire: Ensemble, relevons le défi. Raport pour le ministre de l'éducation et le secrétariat à l'insertion professionnelle:08-04-2010. Retrieved from http://les rapports.ladocumentationfrancaise.fr

Tripier, P. (1991). Du travail à l'emploi, Paradigmes, idéologies et interactions. Bruxelles: Éditions de l’Université de Bruxelles. 


\section{Notes}

Note 1. Direction de l' Évaluation, de la Prospective et de la Performance (Department of Evaluation, Forecasting, and Performance), Ministry of National Education.

Note 2. Centre d'Études et de Recherches sur les Qualifications (Center for Qualifications Research).

Note 3. Inter-regional training and employment portal.

Note 4. Centre Ressources Emploi Formation (Employment and training resource center), GIP Haute-Normandie.

Note 5. Loi d'orientation sur l'éducation (Loi n 89-486 du 10 juillet 1989) (Law on orientation in education, Law number 89-486 of 10 July 1989).

Note 6. ARF: www.arf.asso.fr

Note 7. DALEC: Délégation Académique pour l'Egalité des Chances (School district delegation for equal ppportunity); PRE: Programme Réussite Educative (Educational success Ppogram); CUCS: Contrat Urbain de Cohésion Sociale (Urban contract for social cohesion); CRED: Contrat de Réussite Educative Départementale (Departmental contract for educational success); ARCOL: Accompagnement de Réussite en Collège et Lycées (Guidance of success in middle and high school); EDRESUP: Envie de Réussir mes études supérieures (Desire for success in my higher education); ZEP: Zone d'Éducation Prioritaire (Educational priority zone); REP: Réseau d'Education Prioritaire (Priority education network); ZUS: Zone Urbaine Sensible (Sensitive urban zone); CASNAV: Centre Académique pour la Scolarisation et l'Accueil des Nouveaux Arrivants et des gens du Voyage (District center for the education and welcome of new arrivals and traveling people).

Note 8. CRED: Contrat Réussite Départementale (Departmental success contract).

Note 9. Plan Régional de Développement des Formations Professionnelles (Regional professional training development plan).

Note 10. Associations pour l'emploi dans l'industrie et le commerce (Associations for employment in industry and commerce, commonly called ASSEDIC).

Note 11. Sandrine Malozon, research for her doctoral dissertation "Les professeurs principaux de troisième, acteurs majeurs de l'orientation scolaire et producteurs d'inégalités", defended September 2014, Université de Strasbourg, department of sociology.

Note 12. Martine Caldéroli, vice-president of the Regional Council of Alsace, in the "L'écho des regions" column of the ARF website.

Note 13. Sandrine Malozon, research for her doctoral dissertation "Les professeurs principaux de troisième, acteurs majeurs de l'orientation scolaire et producteurs d'inégalités", defended September 2014, Université de Strasbourg, department of sociology.

\section{Copyrights}

Copyright for this article is retained by the author(s), with first publication rights granted to the journal.

This is an open-access article distributed under the terms and conditions of the Creative Commons Attribution license (http://creativecommons.org/licenses/by/4.0/). 